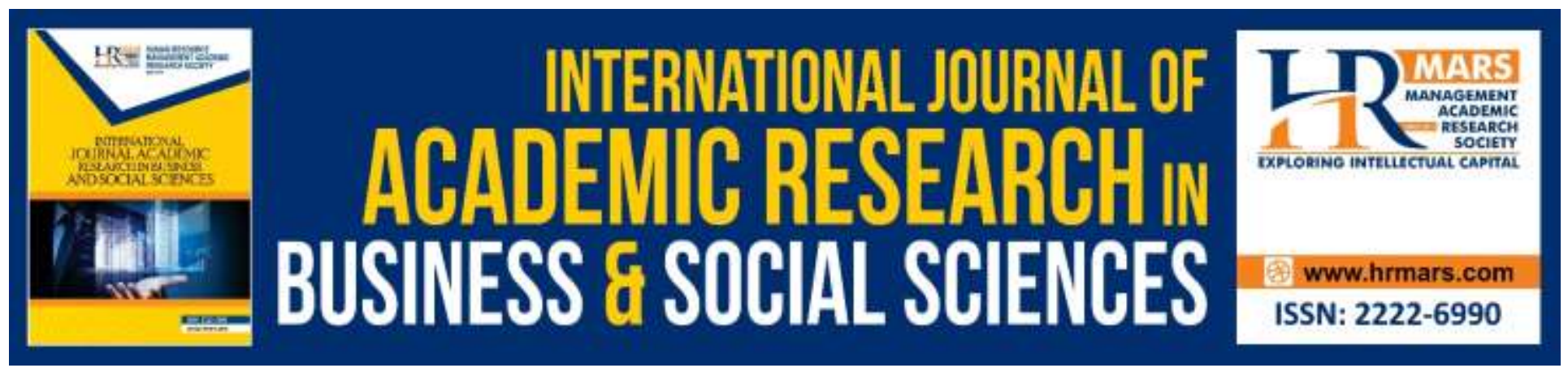

\title{
The Characteristics of Cognitive, Emotional and Social Development of Remedial Students in Learning Numeracy
}

\author{
Jumrah Binti Sultan, Khuan Wai Bing
}

To Link this Article: http://dx.doi.org/10.6007/IJARBSS/v10-i3/7349

DOI: $10.6007 /$ IJARBSS/v10-i3/7349

Received: 14 January 2020, Revised: 20 February 2020, Accepted: 19 March 2020

Published Online: 29 March 2020

In-Text Citation: (Sultan \& Bing, 2020)

To Cite this Article: Sultan, J. B., \& Bing, K. W. (2020). The Characteristics of Cognitive, Emotional and Social Development of Remedial Students in Learning Numeracy. International Journal of Academic Research in Business and Social Sciences, 10(3), 893-901.

Copyright: (C) 2020 The Author(s)

Published by Human Resource Management Academic Research Society (www.hrmars.com)

This article is published under the Creative Commons Attribution (CC BY 4.0) license. Anyone may reproduce, distribute, translate and create derivative works of this article (for both commercial and non-commercial purposes), subject to full attribution to the original publication and authors. The full terms of this license may be seen

at: http://creativecommons.org/licences/by/4.0/legalcode

Vol. 10, No. 3, 2020, Pg. 893 - 901

http://hrmars.com/index.php/pages/detail/IJARBSS

JOURNAL HOMEPAGE

Full Terms \& Conditions of access and use can be found at http://hrmars.com/index.php/pages/detail/publication-ethics 


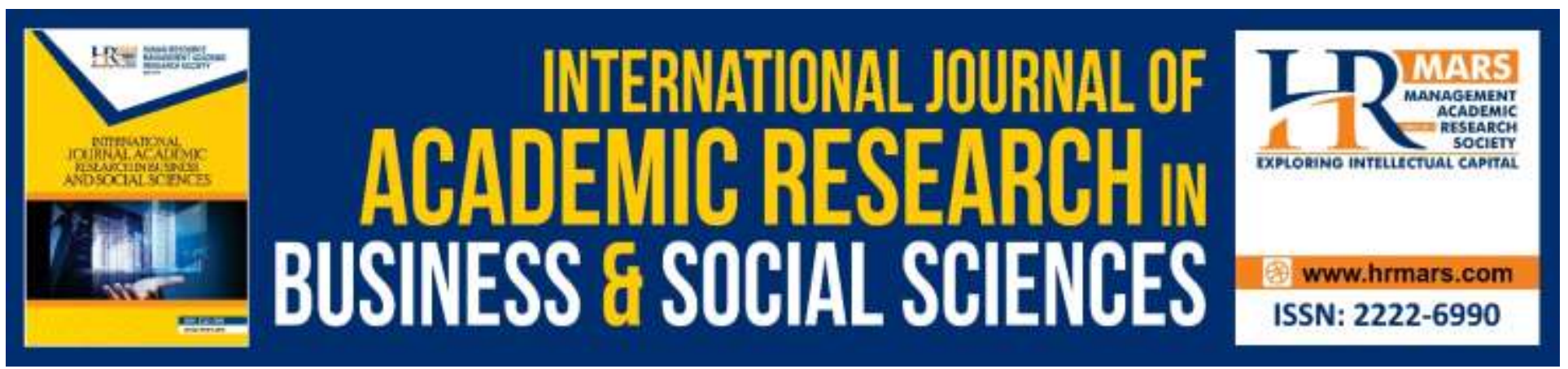

\title{
The Characteristics of Cognitive, Emotional and Social Development of Remedial Students in Learning Numeracy
}

\author{
Jumrah Binti Sultan, Khuan Wai Bing \\ Faculty of Management and Economics, Universiti Pendidikan Sultan Idris, Malaysia \\ Tanjung Malim, Perak, Malaysia. \\ Email: cikgujumrah13@gmail.com
}

\begin{abstract}
This study was conducted to understand the factors affecting the implementation of LINUS Numeracy program for hardcore students in three schools in the Kinta Utara District, Ipoh, Perak. This study used a purpose sampling method in selecting teachers as participants. Interviews, observations and review of documents ware used to gather information. The data was analyzed using content analysis and constant comparative method. The findings showed that the hardcore students have attendance problem, lack of focus during the learning process, health and learning problems, not giving response when questions are asked by the teacher, have no interest in learning and also have family problems. All of these problems will implicate the performance of LINUS in the school, state and the ministry particularly if they are not controlled earlier. Various parties need to play their roles in ensuring the performance of LINUS results is at a commendable level. In this study, there are three main features to focus on the characteristics of cognitive, emotional and social only. There are several programs to attract students and able to increase their achievement for example is extra classes, Numeracy Camps, Out Reach Program, Token Economy and Mentor-mentee.
\end{abstract}

Keywords: LINUS, Numeracy, Students' Achievement, LINUS hardcore, Remedial Students.

\section{Introduction}

Remedial Education is an educational program created for students who are having trouble mastering complex 3M (reading, writing and counting) skills due to the environment. This program needs to be implemented by a dedicated teacher. (Kementerian Pelajaran Malaysia, 2012). The concept of recovery according to Ee (1998) is an activity in teaching and learning sessions to help students in the mainstream stream experience difficulties in mastering the $3 \mathrm{M}$ basic skills. According to Pusat Perkembangan Kurikulum Malaysia (2008), remedial students are those who are having trouble learning certain skills, negative aspects of learning and behaviour that affect learning attitude and 
INTERNATIONAL JOURNAL OF ACADEMIC RESEARCH IN BUSINESS AND SOCIAL SCIENCES Vol. 10, No. 3, March, 2020, E-ISSN: 2222-6990 @ 2020 HRMARS

lack self-confidence and a positive attitude towards learning. Remedial education goal is to ensure that all students master the basic skills of $3 \mathrm{M}$ except students with special needs (Kementerian Pelajaran Malaysia, 2012).

LINUS is an acronym for the word literacy and numeracy. The screening of students according to academic achievement (Literacy and numeracy) was initiated by the Ministry of Education (MOE) in 2010. The main objective of this program is to ensure that all students at level one (Year 1, Year 2 and Year 3 ) are able to master the skills of reading, writing and counting (3M). MOE intends to ensure that students master normal literacy and numeracy skills by 2021. Curriculum Development Division (CDD) is a special organization entrusted to be accountable in spearheading MOE's main objectives in addressing literacy and numeracy problems among primary school students. In LINUS Programme Operational Book 2.0 Kementerian Pendidikan Malaysia (2015) the computer program has content that has been neatly arranged and selected to give students a good guidance in developing mathematical basic skills especially as the program calculates and thus creates a conducive atmosphere during learning. MOE suggested the strategy in an integrated manner so that literacy and numeracy problems can be addressed and improved before these problems become difficult to be controlled. Students who fail in $3 \mathrm{M}$ skills will risk falling behind making it difficult for them to further their studies in the future (Unit Perancang Ekonomi, 2010; Kadir, 2011).

In facing an explosion of education in this day and age, teachers play an important role in ensuring that pupils are able to dominate their learning. The need to educate this generation so as to become useful very important (Rahim \& Abdullah, 2017). Teacher quality, balanced and create a conducive learning environment is important to facilitate the process of Mastery Learning (Hamdan, Sihes, Ramli \& Ismail, 2006). Various teaching approaches are developed and adopted by teachers to ensure that student learning objectives are achievable. The teacher's approach and teaching method is a change that has a different impact on today's education (Tamuri \& Husin, 2017). Teachers' responsibility is not just to communicate information and skills to students, but teachers need to provide teaching equipment for student learning to be more easily understood and accepted by students (Maddahiri, Abdullah, Mosin, Ahmid \& Asul, 2018; Sultan \& Bing, 2018). Planning and implementing programs are also a form of effort to help students understand skills more effectively. The effectiveness of a program is based on the achievement of the objectives of the program. Objectives that are unclear and unintelligible will have an impact on the achievement of the objectives of the planned program (Sani, 2014).

\section{Characteristics of Remedial Students in Learning Numeracy}

Characteristics of students with learning disabilities or remedial students have been categorized into a number of behavioral, cognitive, emotional and social characteristics (Lee \& Lee, 1958; Williams, 1970; Haigh, 1977; Ee, 1998). In this study, there are three main features to focus on the characteristics of cognitive, emotional and social only. According to Koh (1981a), remedial students is who experience difficulty in learning where they do not perform well when compared to the average performance of their peers. 
INTERNATIONAL JOURNAL OF ACADEMIC RESEARCH IN BUSINESS AND SOCIAL SCIENCES Vol. 10, No. 3, March, 2020, E-ISSN: 2222-6990 @ 2020 HRMARS

Table 1 show the findings from the teachers interviewed regarding the characteristics of remedial students. Names of participants used in this article are pseudonyms.

Table 1: Statement of Participants Related to Characteristics of Remedial Students.

\begin{tabular}{|l|l|}
\hline \multicolumn{1}{|c|}{ Participants } & \multicolumn{1}{c|}{ Statements } \\
\hline Puan Fadzlina & Attendance problems, no response \\
\hline Puan Jamiah & $\begin{array}{l}\text { Learning problems, didn't give any answer when questioning, family } \\
\text { problems, weak of self-management. }\end{array}$ \\
\hline Puan Basharina & Attendance problems, health problems. \\
\hline Encik Samsul & Didn't focus in class during learning process, learning problems. \\
\hline Puan Suryani & Dislike attends to school, Other friends don't like them \\
\hline Puan Salwani & Didn't matured compare to others, Born in the beginning of the year. \\
\hline
\end{tabular}

As in table 1, most of participant stated that remedial students have attendance and learning problems. Puan Basharina remarked that the LINUS students don't like go to school because their friends didn't like them. This opinion is agreed by Puan Suryani. Learning problems is the main problem as mentioned by Puan Jamiah and Encik Samsul. Students cannot overcome their learning problems and all of them must attend special class for students who are facing learning problems. Puan Jamiah mentioned that in class, she has to repeat her teaching over and over again to make sure students understand the topic or can construct sentences that they have learnt. Encik Samsul said that one of remedial students did not focus on the learning process and sometimes they disturb their friends. When the teacher asks questions, they didn't respond at all and kept silent. Puan Fadzlina and Puan Jamiah also agreed to this. Puan Salwani provided information related to the development of psychology and cognitive development. These hardcore students have low maturity levels as compared to other peers. They also have weak self-management due to their low maturity levels.

\section{Cognitive}

While in class, remedial students have a relatively weak compared to other normal students. This is because their long-term memory is rather weak where they are difficult to transfer ideas, generalize and unable to anticipate the skills that were taught by teachers in the classroom (Murray \& Lee, 1958). According to Williams (1970), this learning weaker students do not know the methods to learn and understand the skills being taught. They also find it difficult to understand and remember the concepts and relationships of causes and consequences. These remedial students need the help of teachers and are difficult to be independent and less creative in solving problems related to learning. This means that these students find it difficult to associate new knowledge with old knowledge. As a result, they find it difficult to recall what teachers have taught and often make mistakes in carrying out their assigned tasks. Their ability is also low compared to their peers who have moderate achievement in learning. According to Shelton (1971), student achievement can be seen as involving skills such as reading ability, abstract thinking, making connections and generalizing knowledge. Therefore, recovery students need to be given more stimulation and training even when the task assigned is relatively simple (Krishnakumar, Geeta \& Palat, 2006). 
INTERNATIONAL JOURNAL OF ACADEMIC RESEARCH IN BUSINESS AND SOCIAL SCIENCES Vol. 10, No. 3, March, 2020, E-ISSN: 2222-6990 @ 2020 HRMARS

\section{Emotional}

According to Williams (1970), students with learning disabilities have low motivation, lethargy, irritability and lack of responsibility in the matter. Finally, they would be worried if teachers monitored their assignments in the classroom (Haigh, 1977). In building social relationships with other partners, remedial students have a poor adaptive skill (Nieuwenhuijzen \& Vriens, 2012). As a result, this remedial student will be more likely to exhibit aggressive, angry, antisocial, guilty and so on compared to other normal students. This tendency reflects emotional turmoil and ultimately makes the school a place to resolve anxiety and internal conflicts due to problems faced at home (Shelton, 1971). According to him, among these remedial students, these social and emotional factors are closely related to their mental health and psychological factors. Initiatives to develop themselves quite low and do not exhibit a high quality of work is also a remedial student characteristic learning (Lee \& Lee, 1958).

\section{Social}

According to Alesi, Rappo \& Pepi (2015), students with learning disabilities are seen to be socially slow and have poor development in terms of motor development and cognitive ability. The ability to process information is also relatively slow, poor concentration and have a limited working memory. During role-playing activities and interpreting social situations in group discussions, their social capabilities will cause their peers to feel uneasy. These students with learning disabilities also have problems in forming their own image, are immature in interpersonal relationships and have communication problems that eventually lead to psychosocial problems. Therefore, intervention programs in the inclusive classroom are the best way for these remedial students to deal with their psychosocial problems. The classroom environment of the remedial student should focus on individual interaction, expressive and receptive language, self-concept and social roles that can help them develop thinking skills and fit with their environmental needs (Vlachou, Didaskalou \& Argyrakouli, 2006. These social characteristics contribute to the difficulty in mastering numeracy skills and other skills which have led to their lack of interest in the next learning session leading to other issues such as attendance problems and so on.

\section{Enhancement Programs}

The findings are presented in table 2.

Table 2: Statement of participants related to the type of program implementation suitable for Remedial students.

\begin{tabular}{|l|l|}
\hline \multicolumn{1}{|c|}{ Participants } & \multicolumn{1}{c|}{ Statements } \\
\hline Puan Fadzlina & Extra class \\
\hline Puan Jamiah & LINUS Camp \\
\hline Puan Basharina & Out Reach Program \\
\hline Encik Samsul & Economic Token \\
\hline Puan Suryani & Mentor- mentee \\
\hline Puan Salwani & Mentor - mentee \\
\hline
\end{tabular}

The program activities implemented for remedial students include extra classes, LINUS camp, Out Reach Program, Economic Token and Mentor-Mentee. 
INTERNATIONAL JOURNAL OF ACADEMIC RESEARCH IN BUSINESS AND SOCIAL SCIENCES

Vol. 10, No. 3, March, 2020, E-ISSN: 2222-6990 ¿ 2020 HRMARS

\section{Extra Class}

This program was conducted in accordance with the set class schedule. It was carried out early in the morning in special classes called Remedial classes that have good facilities such an air conditioning room and learning aids to ensure student's comfort during learning the process. Teachers will give pencils or books to students as a present to motivate them for their good attendance. The parent's role to send their children early to school is very important for the punctual attendance of students.

\section{LINUS Camp}

This LINUS camp program has two phases. The first phase is the making of teaching aids attended by teachers only. This collaboration involves not only LINUS teachers, but also other teachers in the school. The second phase of the program is the phase for students. Teachers will be divided into groups and placed according to the stations based on skills to be assessed. Students will be in groups and will move from one station to another station until they have gone to all the stations. At every station, the teacher will help students with a particular skill. This program helps students prepare before the actual screening of their skills.

\section{Out Reach Program}

The aim of this program is to identify students who are having problems hardcore problems. The program is suitable for finding similar symptoms with previous LINUS students or looking for new symptoms to ensure that the numeracy deterioration can be addressed. The program is also supported by a special education teacher to detect potential students from becoming disciples of remedial student. The teachers are experienced in identifying these students through a number of methods such as writing and speaking verbally.

\section{Economic Token}

This program is very popular among students. This is because students will be rewarded based on their skills and ability to complete the assignment given by the teacher or be able to use the learned skills. Rewards are given to encourage their motivation to strive to reach their desired reward. The token is in the form of a star. The student who successfully answers the teacher's question or use the learned skills will be given the token. Collected tokens can be converted into various rewards.

\section{Mentor- mentee}

This program involves collaboration with teachers. A pupil will be adopted as a child to a teacher. Teachers will provide encouragement or guidance to their adopted students as a step to help them and at the same time learn more about the problems faced by the child.

\section{Discussion}

This study is a qualitative study in which the findings are collected through interviews, observations and document analysis. The selection of research participants is based on the criteria set by the researchers such as having experience in teaching Mathematics and have a specific position involving LINUS program namely remedial teacher, LINUS coordinator, special education teacher and head of 
INTERNATIONAL JOURNAL OF ACADEMIC RESEARCH IN BUSINESS AND SOCIAL SCIENCES Vol. 10, No. 3, March, 2020, E-ISSN: 2222-6990 @ 2020 HRMARS

Mathematical subject committee. The data of this study was analyzed using content analysis and also constant comparative method. Both of these methods help researchers analyze the data and make comparisons of the results from each participant. In this study, the researchers discovered several new findings of the remedial students.

The findings showed that several characteristics of remedial students, among them being attendance problems, lack of focus during the learning process, health and learning problems, no response and maintaining silence when being questioned by teachers, not interested and have family problems. Most participants regarded the issue of absenteeism in school as the main cause of the student's failure in numeracy. This finding is consistent with the results of interviews conducted by Sani (2014) that the problem of being present in school is one of the factors hampering the mastery of the remedial students towards literacy or numeracy.

This study also indicated that some of the programs in the school such as extra class, LINUS Camp, Out Reach Program, Token Economic and Mentor-Mentee Program help the students. Most programs help students in terms of motivation and increase their numeracy skills. This finding is in line with the study conducted by Chew (2015) in which students improved their performance with the LINUS program being implemented.

The programs that is preferred by most schools include the Mentor-mentee Program has a great impact on the students. This program makes the teacher a mentor or in other words promoting the teacher as a good role model. This finding is in line with the findings of the study conducted by Sani (2014) where the program provided space and opportunity for teachers and students to interact on a one-to-one interaction.

Another program that attracts teachers is the Economic Token Program. The program is also highly favoured by remedial students because students will try to collect tokens to get the rewards (e.g. toy, pen and others) that have been shown by the teacher. Through an interview with one of the participants in the study that handled this program, not only the attendance problem can be overcome, but the motivation of the student can be seen increasing as well. This is because the teacher has shown the rewards to the students and they can work towards collecting their token and exchanged it with a reward of their choice. This program is unique because the reward is something normal for anyone, but the technique shows reward in advance that allow students to choose the reward they are interesting is a new strategy for research and is in line with the behavioural theory expounded by Bandura (1977) in which learning starts when the students act with stimulus (McLeod, 2011)

\section{Conclusions}

The study of the management of student achievement in the LINUS HARDCORE Numeracy Program has been implemented in accordance with the resolution that has been designed. The findings of the study have helped the researcher to do further research improvements through the achievement of the objectives and questions of the study being answered. Through the findings of the study, the researcher has provided some of the research recommendations that can be used as a source of research for other researchers. It is hoped that all parties, especially the schools can successfully implement programs that have been designed carefully as well as the cooperation of the community, especially in ensuring that children do not drop out of the learning process. The teacher's role is very 
INTERNATIONAL JOURNAL OF ACADEMIC RESEARCH IN BUSINESS AND SOCIAL SCIENCES

Vol. 10, No. 3, March, 2020, E-ISSN: 2222-6990 C 2020 HRMARS

important in the success of any program in the school, and the success of a program will not succeed if it does not have the support from all of parties.

\section{Corresponding Author \\ Khuan Wai Bing}

Faculty of Management dan Economics,

Universiti Pendidikan Sultan Idris, Malaysia

Tanjung Malim, Perak, Malaysia.

Email: khuan.wb@fpe.upsi.edu.my

\section{References}

Alesi, M., Rappo, G., \& Pepi, A. (2015). Emotional profile and intellectual functioning: a comparison among children with borderline intellectual functioning, average intellectual functioning, and gifted intellectual functioning. SAGE Open, 5(3), 2158244015589995.

Bandura, A., \& Walters, R. H. (1977). Social learning theory (Vol. 1). Englewood Cliffs, NJ: Prenticehall.

Chew, F. P. (2015). Pelaksanaan Program Literasi Dan Numerasi (Linus) Di Sekolah Rendah. Jurnal Pendidikan Bahasa Melayu-JPBM (Malay Language Education Journal-MyLEJ). Universiti Melaya.

Ee, A. M. (1998). Pedagogi III: Pengujian dan penilaian, pemulihan, pengayaan, dan pendidikan inklusif (Semester IV). Shah Alam: Fajar Bakti.

Haigh, G. (1977). Teaching slow learners. London: Maurice Temple Smith Ltd.

Hamdan, A. R., Sihes, A. J., Ramli, J., \& Ismail, M. (2006). Tahap minat, pengetahuan dan kemahiran, latihan guru Dan beban tugas guru program Pemulihan Khas sekolah kebangsaan daerah Pontian, Johor. In Annual Conference on Teacher Education (pp. 6-8).

Kadir, Z. A. (2011). Sudut Pandang Muhyidin Yassin. Institut Terjemahan Negara Malaysia

Kementerian Pelajaran Malaysia. (2012). Garis Panduan Pelaksanaan Program Pemulihan Khas. Kuala Lumpur: Bahagian Pendidikan Khas, Kementerian Pelajaran Malaysia.

Kementerian Pendidikan Malaysia. (2015). Buku Pengoperasian Program LINUS 2.0, Putrajaya: Kementerian Pendidikan Malaysia. Bahagian Pembangunan Kurikulum (BPK)

Krishnakumar, P., Geeta, M. G., \& Palat, R. (2006). Effectiveness of individualized education program for slow learners. The Indian Journal of Pediatrics, 73(2), 135-137.

Lee, J. M., \& Lee, D. M. (1958). The child and his development. New York: Appleton Inc.

Maddahiri, A. B., Abdullah, M. K., Mosin, M. B., Ahmid, M. H. B., \& Asul, H. B. (2018). LINUS-literacy teaching practices. Malaysian Journal of Social Sciences and Humanities (MJSSH), 3(2), 32-39.

Mcleod, S. S. (2011). Bandura - Social Learning Theory. Retrieved from www.simplypsychology.org/bandura.html

Pusat Perkembangan Kurikulum, (2008). Pendidikan di Malaysia. Kuala Lumpur: Kementerian Pelajaran Malaysia.

Rahim, N. A., \& Abdullah, A. H. (2017). Kesediaan Guru Matematik Sekolah Menengah Dalam Melaksanakan Proses Pembelajaran dan Pengajaran Abad Ke-21.Isu-isu Pendidikan Kontemporari. 
INTERNATIONAL JOURNAL OF ACADEMIC RESEARCH IN BUSINESS AND SOCIAL SCIENCES

Vol. 10, No. 3, March, 2020, E-ISSN: 2222-6990 @ 2020 HRMARS

Sani, N. (2014). Pelaksanaan Program Literasi \& Numerasi (LINUS): Satu Analisis (Doctoral dissertation, Jabatan Pengurusan, Perancangan dan Dasar Pendidikan, Fakulti Pendidikan, Universiti Malaya).

Shelton, B. O. (1971). Teaching and guiding the slow learner. West Nyack, N.Y: Parker Publishing Company, Inc.

Sultan, J. B., \& Bing, K. W. (2018). Management of Linus Hardcore Students ' Achievement in Elementary School Numeracy Program. Pembentangan Kajian dalam $8^{\text {th }}$ UPIUPSI International Conference, Oktober 8, 2018, Grand Tjokro Hotel Bandung Indonesia. (page 290-293).

Tamuri, A. H., \& Hussin, N. H. (2017). Pembelajaran Abad Ke 21 dalam Kepelbagaian Budaya: Harapan Dan Cabaran. In Seminar Pedagogi Antarabangsa Ke-8 (PEDA8) (Vol. 8, pp. 1-12).

Unit Perancang Ekonomi. (2010). Rancangan Malaysia ke-10; 2011-2015. Kuala Lumpur: Percetakan Nasional Malaysia Berhad.

Van Nieuwenhuijzen, M., \& Vriens, A. (2012). (Social) Cognitive skills and social information processing in children with mild to borderline intellectual disabilities. Research in developmental disabilities, 33(2), 426-434.

Vlachou, A., Didaskalou, E., \& Argyrakouli, E. (2006). Preferences of students with general learning difficulties for different service delivery modes. European Journal of Special Needs Education, 21(2), 201-216.

Williams, A. A. (1970). Basic Subjects for the slow learners. London: Methuen Educational Ltd. 